\title{
Key Competencies of Agricultural Managers in the Acute Stage of the COVID-19 Crisis
}

\author{
Nadežda Jankelová (D) and Juraj Mišún *(D) \\ Department of Management, Faculty of Business Management, University of Economics in Bratislava, \\ 85235 Bratislava, Slovakia; nadezda.jankelova@euba.sk \\ * Correspondence: juraj.misun@euba.sk; Tel.: +421-2-6729-5606
}

check for updates

Citation: Jankelová, N.; Mišún, J. Key Competencies of Agricultural Managers in the Acute Stage of the COVID-19 Crisis. Agriculture 2021, 11, 59. https://doi.org/10.3390/ agriculture11010059

Received: 13 November 2020 Accepted: 11 January 2021 Published: 13 January 2021

Publisher's Note: MDPI stays neutral with regard to jurisdictional clai$\mathrm{ms}$ in published maps and institutional affiliations.

Copyright: (C) 2021 by the authors. Licensee MDPI, Basel, Switzerland. This article is an open access article distributed under the terms and conditions of the Creative Commons Attribution (CC BY) license (https:// creativecommons.org/licenses/by/ $4.0 /)$.

\begin{abstract}
The acute phase of the COVID-19 crisis exacerbated the need for managerial skills of agricultural managers, provoked another wave of discussion on content of managerial competencies in times of crisis, and revealed a significant research gap. The main goal of our study is to identify the impact of competencies of agricultural crisis managers on the performance of employees in the acute phase of the crisis, when the performance was influenced by their subjective perception and evaluation of their working conditions, satisfaction and safety. We used statistical mediation to examine the connections and deeper relationships between several variables. The hypothesis of dependence between competencies of crisis management and performance of employees, mediated by information sharing, teamwork and cognitive diversity, has been confirmed. Partial mediation has been identified, when only part of the effect is mediated by the mediator variables, however the substantial one. The remaining, smaller part is transmitted directly. Employees' performance in an acute crisis phase can be influenced by competent crisis management and enhance its effect through information sharing and teamwork support. The cognitive diversity of crisis management did not prove significant in our study. The emphasis is on consistency and the resulting sense of security and safety.
\end{abstract}

Keywords: management competencies; crisis management; agricultural management; acute phase of a crisis; COVID-19 pandemic; information sharing; teamwork

\section{Introduction}

The COVID-19 pandemic hit Slovakia in early March 2020 and pointed to the fact that, like health care, a steady supply of agricultural products is essential for the smooth handling of such a crisis. Agricultural managers also had to become crisis managers, however, often without the necessary managerial skills. In addition to solving production problems, they also had to deal with sales, with human resource management, with the ability to make effective decisions, strategically plan, lead people in a way that ensures feelings of security, trust and safety, communicate or share information. Their primary aim was to ensure optimal working conditions for their employees, who could subsequently fulfill their obligations to customers. Despite unprecedented challenges, agricultural enterprises have been forced to take all possible measures to ensure the safest possible performance of employees and to fulfill critical tasks in securing food supplies. Simultaneously, crisis response determines the recovery trajectory and the future for business performance [1] and, therefore, requires management that responds flexibly to the problems that arise and is able to make decisions in conditions of uncertainty. It is not only important to handle the crisis immediately, but also to learn from it and transfer the experiences gained to the post-crisis period. According to Sheth [2], the best way to survive the current crisis is to learn from the past where multigenerational relationship with different stakeholders saved companies.

Current articles on the crisis competencies of agricultural managers in the time of COVID-19 pandemic are presented mainly in the form of popular literature or newspa- 
per articles. There is a lack of relevant scientific studies and their findings, which have subsequent implications for the practice of these managers.

In agrarian research, there are analyses of the impact of the pandemic on both the supply chain [3-5] -including transportation [6] and agricultural labor supply [7] —and demand [8]. The crisis can lead to long-term changes in the form of increased automation and robotics [8,9] and pressure on food self-sufficiency [5,8,9]. Altieri and Nicholls [10] offer agroecology as a long-term solution. In addition to these issues, however, managerial aspects are very important in the acute phase of the crisis, especially the crisis skills of managers, who should provide reassurance to people and employees in a tense and critical situation.

The acute phase of the COVID-19 crisis, characterized by various emotions related to concerns for the health (of the manager himself and his subordinates) and with the effort to ensure the supply of food for the population, exacerbated the need for managerial skills. During this phase, crisis management needs to direct and coordinate available resources [11]. However, Yu et al. [12] see a potential challenge for the classical four-stage crisis lifecycle (prodromal, acute, chronic, and resolution stage), since "risk perception and communication intensity experienced a dynamic change in communication on social media due to the rapid and unpredictable spread of the epidemic (p. 4)."

Competencies of crisis management (CCM) represent certain skills and competencies that a crisis manager should have in relation to the expectations of the external and internal environment. The most important crisis skills include crisis communication, leadership styles and decision making [13].

The crisis provoked another wave of discussions on the content of managerial competencies of agricultural managers in such turbulent times and at the same time revealed a significant research gap. Current papers in the context of the COVID-19 pandemic, focused on managerial competencies, are mainly on the level of essays, theoretical research, analysis of secondary sources and subsequent identification of recommendations. Verma and Gustafsson [14], for example, examined the impact of COVID-19 on different facets of businesses through bibliometric analysis, while Ratten [15] posits that it is essential to incorporate more entrepreneurial thinking into the research on the current crisis.

Tourish [16] draws attention to the leadership crisis that coincided with the current crisis and calls on authors to examine and identify the dynamics of leadership skills during a pandemic. Grint [17] states that in times of a pandemic, we need charismatic leaders who are said to defeat the virus with their positivity and leaders who can contextualize the situation. Wilson [18] synthesizes findings into key leadership practices such as to be led by expertise, mobilizing collective effort and enabling coping. Wisittigars and Siengthai [19] found that, in the context of Thai facility management, emergency preparedness and crisis communication were the top two crisis competencies. To improve the performance of (public) leaders under the current pressure, Trachsler and Jong [20] propose the adoption of behavioral and psychological knowledge from sports management, as there are similar circumstances (uncertainty, limited control and high expectations). Comfort et al. [21] highlight the importance of crisis decision making and cognition support, while focusing on agility, transparency, participation and communication skills [22]. As part of communication competencies in crisis times, managers must avoid so-called suboptimal anomalies, which, unlike optimal crisis response strategies, cause reputational damage to organizations [23]. During the COVID-19 pandemic, communication with employees plays an essential role also in the case of family firms [24]. For investigating organizational communication, Stephens et al. [25] propose a list of 24 research questions, which were evoked by the pandemic. Given the complexity of decision making during a crisis and disaster, Al-Dabbagh [26] considers that there is a need for a scientific thinking method that can turn such a crisis into a normal problem with possible solutions. Obviously, during the COVID-19 pandemic, leadership, decision making and communication are an important part of managerial competencies, and the crisis has revealed many partial as well as systemic shortcomings in these capabilities, sometimes with fatal consequences. 
The research gap, which is the starting point for the formation of the research model of our study, is the content of competencies of crisis management and its impact on the performance of employees in agricultural enterprises in Slovakia during the acute phase of the COVID-19 crisis. It is necessary to evaluate the relationship between these two variables, as in the acute phase of the crisis, performance should not immediately be in focus. Rather, the interest has to be focused on the current perception and subjective feelings of employees [27], for whom it is necessary to create a safe working climate and working conditions, to ensure their satisfaction and confidence in management of the company. In the acute crisis phase, the possibility to measure employee performance through quantitative indicators is limited. However, a prerequisite for the effective functioning and performance of employees in acute crisis conditions is the creation of suitable conditions for its activities and recommendations for the future. In the subsequent crisis and post-crisis phase, performance measurement is already possible and the goal of management should be that the results achieved are at an excellent level. The results and findings of our study, based on authentic statements from lower-level agricultural managers, who were forced to ensure the smooth running of their enterprises and the food security of the population in times of fear, uncertainty, anxiety and lack of information, represent a significant scientific contribution to agricultural management and crisis management in this sector.

\section{Theoretical Background}

Means and practices of crisis management can prevent or minimize the impact of crises [28]; its main goal is to bring back normalcy [29]; and it involves multiple subjects, which have to work together to prepare for, handle and recover from crisis [30]. It is a dynamic process of interconnected phases that are significantly affected by each other [31]. The authors claim that the pre-crisis phase of management significantly affects both the crisis phase and the phase immediately following the crisis. Therefore, organizations, which are well prepared to carry out their activities already in the pre-crisis period, can identify the signals of an upcoming crisis very well, recognize it, manage its course and learn from it. The basis of successful crisis management are CCM, defined as certain skills and competencies, especially crisis communication, leadership styles and decision making, which the crisis manager should have in relation to the expectations of the external and internal environment [13]. Bernstein [32] and Moerschell and Novak [13] consider the pre-crisis phase as an essential opportunity to establish a crisis communication response team and anticipate possible future disruptions to the organization. Conscientious precrisis preparation prevents leadership from reactive behavior at the onset of a crisis and enables it to proactively communicate, lead, and make decisions in subsequent phases to mitigate negative long-term consequences [33]. The post-crisis phase is characterized by the evaluation and audits of crisis activities, as well as recovery, while CCM again plays an important role in building the image, reputation, renewal of relationships with all stakeholders.

If we consider CCM as the ability to communicate, lead and make decisions in times of crisis, it is necessary to define certain common features that individual skills, based on many authors, contain. The first component of CCM is the ability to communicate effectively. Several studies point out that effective communication in particular is an important factor in successful handling of a crisis, especially its acute phase [34,35]. Effective communication is expected to reduce the uncertainty that can provoke an emotional response from the public or employees, therefore persuasiveness is an important element [36,37]. By means of a content analysis of leaders' communication messages during the Middle East respiratory syndrome (MERS) health crisis, You and Ju [38] found a tendency for leaders to emphasize their control of the crisis situation.

Crisis communication is a key task of management in times of crisis. Research in the field of crisis communication has recently developed mainly in the field of external crisis communication, and internal communication in times of acute crisis has been neglected. However, from the point of view of employees as well as the organization, it is the internal 
communication that contributes to the handling of the crisis situations, as it is necessary for decision making and teamwork. It can significantly support the cohesion of staff, especially in difficult conditions of social isolation [39]. Effective internal communication during a crisis is expected to reduce employee insecurity, which can cause an emotional response [40]. Management needs to demystify the situation and provide hope for the future. According to Argenti [41], studies have proved that leaders have a special role to play in reducing employee anxiety. In his previous study on crisis communication after 9/11 [42], many employees described how important it was to hear the voice of their superiors, either directly or through e-mail, telephone messages or social media. Leaders need to recognize and support the coordination of expertise and communication, as key aspects of teamwork [43]. Research-based advice on managing teamwork, actionable and feasible in the midst of a crisis, is offered by Tannenbaum et al. [44].

The internal dimensions of crisis communication are insufficiently researched also because the results of crisis management are directly related to the perception of employees, the creation of feelings, reactions and actions. As an organization enters an acute phase of a crisis, the need for information increases among employees dramatically. They act according to their own understanding of the situation and at the same time discuss the crisis with all stakeholders. Johansson and Ottestig [45] found that managers overestimate their external legitimacy over the internal one, and this is reflected in insufficient communication activity in relationship to employees. According to Boin et al. [36], the main parameters of communication of leaders in crisis are their ability to offer a credible explanation of what happened, provide guidance through the crisis, instill hope by emphasizing the positive aspects and positively represent the likelihood of successful problem solving, express empathy for crisis and constantly indicate that management has control over the situation, emphasize its own responsibility and take appropriate steps to overcome the crisis situation. Other authors perceive the importance of encouraging individuals in internal communication, which leads to an appropriate and desirable response. Simultaneously, regular communication on the effectiveness of measures taken leads to higher compliance [46]. Coombs [47] and Argenti [41] state that communication of management should be perceived by employees as honest, sincere, trustworthy, and should be transparent and open. Optimally, the role of communication partner should be taken over by the company's chief executive officer (CEO) or another member of top management. Communication with employees should be on a regular basis, several times a week [48]. The personal and empathic nature of communication is extremely important at this stage of the crisis. It contributes to the bonding of employees and encourages the creation of "we-feeling". Although there is literally a flood of information about COVID-19, it is often unverified, even fake, and arouses concern and anxiety among recipients. Therefore, the basis is to provide employees with correct processed and accurate information.

An appropriate leadership style is also one of the important competencies of crisis management [49-51]. James et al. [52] point to the formation of effective leadership styles under the influence of the expectations that employees have from their managers. This is especially important in times of crisis, as employees are key stakeholders in crisis management. In a crisis period, employees expect the leader will successfully handle it and will help them to easily overcome difficult obstacles. They want to lean on him, they demand support from him, they want to feel his interest and empathy, and subsequently they want to help him through cooperation and shared leadership [53].

In addition to communication and leadership style, an important part of the competencies of crisis management is the ability to make adequate decisions [54,55]. An important prerequisite for the correct decision is the ability to think critically, to perceive information in context and to be oriented in a problem [56]. Organizations, which are favoring adaptive culture with more informed and decentralized decision making, are more likely to sustain business operations during the current pandemic [57]. In times of crisis, management needs to be able to analyze different solution options, constantly learn from real-life situations, and respond flexibly to them, which is related to the existence of effective crisis 
management in the pre-crisis period [58]. Unfortunately, as Goniewicz et al. [59] point out, many decisions made during the COVID-19 crisis were focused mainly on political and economic considerations, although public safety and security should have been in the foreground. Recently, the need for cognitive diversity of the crisis team has been added to crisis decision making research, providing different perspectives on the situation and possible solutions $[60,61]$.

The combined action of these factors is a prerequisite for successfully coping with difficult conditions and preparing for new, often changed post-crisis functioning. It is also a condition for high performance during crisis periods [62-64], which is conditioned by the optimal work performance of employees. During the acute phase of the crisis, the performance can be evaluated by the feelings of satisfaction, safety and the creation of conditions for work [27].

Based on the aforementioned, we formulate our first hypothesis as follows:

Hypothesis 1 (H1). We assume that CCM are positively associated with employee performance (EP).

Based on published studies $[65,66]$, in addition to the content of CCM, it is important to explore cognitive diversity (CD), information sharing (IS) and teamwork (TW) as key qualities of crisis management through which a positive association with employee performance $(\mathrm{EP})$ can be transmitted.

IS is a critical team process because if knowledge is not shared and adapted in teams, then individuals' cognitive resources remain underused [64,67]. It is also a tool that ensures individual and team performance through familiarization of employees with the vision, mission and goals of the organizations, through clear, timely, regular information about current problems and facts [46]. Aragon-Correa et al. [68] even point to the positive effects of IS in uncertain environments and in environmentally oriented companies, which include organizations in the agricultural sector.

$\mathrm{CD}$ has been conceived as the degree to which team members differ in terms of expertise, experience, knowledge, skills, thinking styles, values and beliefs [69]. According to Mitchell et al. [65] such a diversity influences the adoption of innovative solutions and improves processes through the breadth of expertise available to inter-functional groups. The $C D$ of a team has potential effects on its results [70] due to the unique perspective and cognitive resources of members, the combination of ideas in new ways, the use of differences in members' knowledge. The impact of CD on performance is considered positive, especially in situations where creative potential is important. In the acute phase of a crisis, the ability to recognize a new path of recovery and eliminate uncertainty is important. In this, we see the way in which organizations, through CCM, achieve the goal of EP.

CCM in the form of appropriately selected tools of communication, ways of choosing a leadership style or approaches to decision making, affect TW in times of crisis. TW is a tool for effective involvement of employees in necessary business activities in times of crisis and consequently contributes to feelings of satisfaction and safety [71], to increase loyalty [72] and employee confidence [73], to increase their performance [74] and overall business performance [75].

Based on this, we formulate further hypotheses as follows:

Hypothesis $\mathbf{1}$ (H1a). CCM are positively related with IS in times of crisis.

Hypothesis $\mathbf{1} \mathbf{( H 1 b )}$. IS in times of crisis is positively related with EP.

Hypothesis $\mathbf{1}$ (H1c). CCM are positively related with TW in times of crisis.

Hypothesis 1 (H1d). TW in times of crisis is positively related with EP.

Hypothesis 1 (H1e). CCM are positively related with $C D$. 
Hypothesis 1 (H1f). CD is positively related with EP.

Based on current knowledge and identification of a research gap in agricultural management research, we formulated a research design for the purposes of this study, which is illustrated by the relations in Figure 1. The main hypothesis tests the relationship between CCM and EP mediated by IS, TW and CD of crisis management.

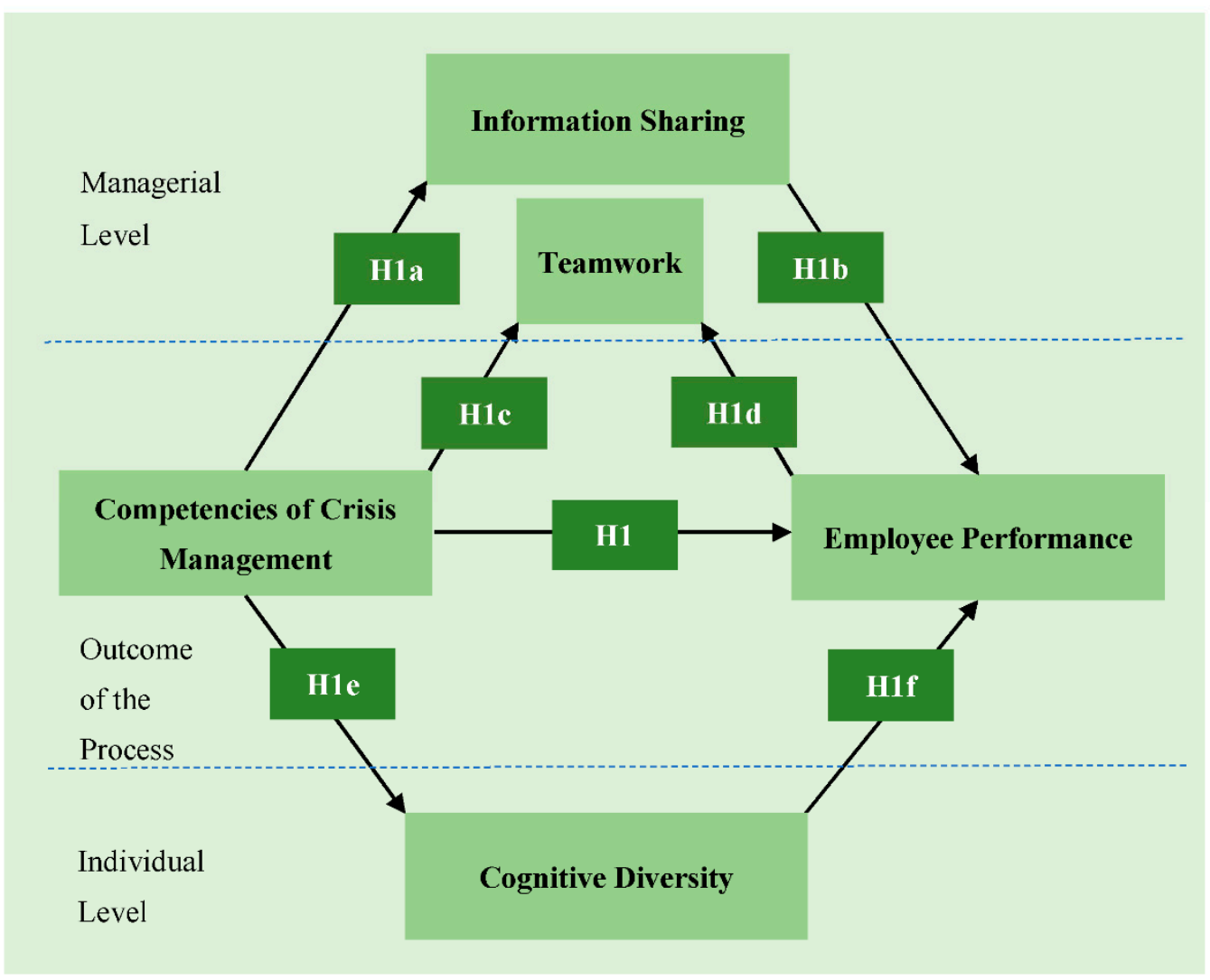

Figure 1. Mediation model and the seven tested hypotheses.

\section{Materials and Methods}

\subsection{Sample and Data Collection}

The data needed to verify the hypotheses were obtained through a quantitative survey conducted online in the form of a questionnaire. We contacted 1266 companies operating in Slovak Republic in the field of primary agricultural production, included in the database of INFOMA Business Trading. The return rate was $16.8 \%$, which means that the size of the surveyed sample is 213 respondents of various structure in terms of legal form, production orientation, number of employees, cultivated land, and higher territorial unit of Slovak Republic. The questionnaire was distributed in the second half of March and early April 2020 (the acute phase of the COVID-19 crisis in Slovakia) and was divided into four parts. The first part contained the identification data of the company, the other parts contained items from the aforementioned model (Figure 1), which were scaled. The structure of the sample of respondents is given in Table 1. 
Table 1. Characteristics of the research sample.

\begin{tabular}{|c|c|c|c|c|c|c|c|}
\hline Variable & Category & Frequency & $\%$ & Variable & Category & Frequency & $\%$ \\
\hline \multirow{4}{*}{ Legal form } & A.C. & 54 & 25.4 & \multirow{4}{*}{$\begin{array}{c}\text { Size } \\
\text { (no. of em- } \\
\text { ployees) }\end{array}$} & $1-9$ & 15 & 7.0 \\
\hline & Ltd. & 139 & 65.3 & & $10-49$ & 88 & 41.3 \\
\hline & JSC & 20 & 9.4 & & $50-249$ & 110 & 51.6 \\
\hline & & 213 & 100.0 & & & 213 & 100.0 \\
\hline \multirow{4}{*}{ Gender } & male & 125 & 58.7 & \multirow{4}{*}{ Education } & secondary & 82 & 38.5 \\
\hline & female & 88 & 41.3 & & 1st degree university & 41 & 19.2 \\
\hline & & 213 & 100.0 & & 2nd degree university & 90 & 42.3 \\
\hline & & & & & & 213 & 100.0 \\
\hline \multirow{6}{*}{$\begin{array}{l}\text { Age of the } \\
\text { respondent }\end{array}$} & $\leq 25$ & 32 & 15.0 & \multirow{6}{*}{$\begin{array}{l}\text { Industry } \\
\text { experience } \\
\text { (in years) }\end{array}$} & $<5$ & 36 & 16.9 \\
\hline & $26-35$ & 70 & 32.9 & & $5-10$ & 45 & 21.1 \\
\hline & $36-45$ & 82 & 38.5 & & $11-15$ & 74 & 34.7 \\
\hline & $46-55$ & 15 & 7.0 & & $16-20$ & 38 & 17.8 \\
\hline & $\geq 56$ & 14 & 6.6 & & $>21$ & 20 & 9.4 \\
\hline & & 213 & 100.0 & & & 213 & 100.0 \\
\hline \multirow{9}{*}{$\begin{array}{l}\text { Position in } \\
\text { management }\end{array}$} & non-managerial & 3 & 1.4 & \multirow{9}{*}{$\begin{array}{l}\text { Higher } \\
\text { territorial } \\
\text { unit of the } \\
\text { Slovak } \\
\text { Republic } \\
\text { (HTU) }\end{array}$} & Banská Bystrica & 35 & 16.4 \\
\hline & lower & 108 & 50.7 & & Bratislava & 35 & 16.4 \\
\hline & middle & 79 & 37.1 & & Košice & 19 & 8.9 \\
\hline & senior & 23 & 10.8 & & Nitra & 33 & 15.5 \\
\hline & & 213 & 100.0 & & Prešov & 25 & 11.7 \\
\hline & & & & & Trenčín & 20 & 9.4 \\
\hline & & & & & Trnava & 19 & 8.9 \\
\hline & & & & & Žilina & 27 & 12.7 \\
\hline & & & & & & 213 & 100.0 \\
\hline
\end{tabular}

A.C. $=$ Agricultural Cooperative, Ltd. $=$ Limited, JSC $=$ Joint Stock Company.

All data were analyzed using the SPSS 22.0 software package. Cronbach's a coefficient was used to assess the internal consistency reliability of scales. We used the Baron and Kenny's method for mediation and the Freedman-Schatzkin test for testing the mediating effect. A series of regression analyses were used to identify the proposed hypotheses. Partial R2 $(\Delta \mathrm{R} 2), \mathrm{F}$ test and standardized regression coefficient $(\mathrm{b})$ and their test statistics $(t$ value) were reported in all regression analyses. The control variables were the legal form of the enterprise, the size of the enterprise (number of employees), the higher territorial unit of operation, and the respondent's gender, age, education, experience and position in management. Analysis of variance (ANOVA) was used to analyze the multiple dependence. We set a significance level of $5 \%$. Confirmatory factor analysis with the method of fixing the variance of factors, the method of estimates and the method of factor-based average score were used to examine and verify the influence of individual factors.

\subsection{Measures}

To test the relationships between CCM, EP and the mediating variables IS, TW and $\mathrm{CD}$, a mediator model was used in order to examine the relationships and processes that occur between the identified variables in more depth.

CCM is an independent/explanatory variable, which is operationalized as a score obtained by the organization's crisis management based on the evaluation of three itemscrisis communication, leadership styles in crisis times and decision making in crisis times. Each evaluated item consists of sub-items.

Crisis communication contains eight items, e.g., "Management supports two-way communication in times of crisis", "I perceive communication from management in times of crisis as honest, sincere, I trust it", "I perceive communication from management in times of crisis as transparent". After reliability analysis, the Cronbach's a of the crisis communication was 0.948 (eight items).

The leadership style contains 10 items, for example: "Management sets an example to its employees in times of crisis", "Management shows confidence in its employees in times 
of crisis, even if they fail", "Management provides the necessary support to employees in times of crisis". After reliability analysis, the Cronbach's a of leadership style was 0.946 (10 items).

Decision making in times of crisis contains eight items, e.g., "Management decisions are quick in times of crisis and management takes responsibility for them", "Management is able to critically evaluate information in times of crisis", "Management is able to analyze various solutions in times of crisis". After reliability analysis, the Cronbach's a of the decision making was 0.953 (eight items).

In total, the independent variable CCM contains 26 items, which are scaled using 5-point Likert-type scales $(1=$ "strongly disagree" to $5=$ "strongly agree"). After reliability analysis, the Cronbach's a of the summary variable CCM was 0.98 (26 items).

By confirmatory factor analysis, completed by a statistical test of the hypothesis of the suitability of the selected factor structure, we confirmed the defined factor structure within the CCM variable, where communication, leadership and decision making items are saturated with three different factors. Nevertheless, they can be used as a whole, because the assignment we assumed is one of the possibilities, so it is not unique (the CFI coefficient that compares the assumed model with the worst possible baseline model was 0.74 ; the Chi2 $p$-value was 0.000$)$. Other criteria of confirmatory factor analysis were satisfactory (assignment-one item-one factor; signs for factor saturation (positive/negative)—all saturated positive, coefficient SRMR $=0.054$; RMSEA $=0.079$ ).

The second variable is the dependent variable EP. The variable performance is operationalized as a score assigned to individual items, representing job satisfaction, a feeling of safety and quality and safe working conditions. We used the Safety Attitudes Questionnaire (SAQ), which was validated by many researchers and was developed to identify managerial attitudes to work performance issues in terms of teamwork climate, job satisfaction, perceptions of management, safety climate, working conditions, stress recognition, even in exceptional situations, which the current pandemic clearly is [76]. After reliability analysis, the Cronbach's a of EP was 0.941 (ten items). Examples of items of the variable are: "This company is a good place to work, even in a crisis", "I am proud to work in this company because of the handing of the crisis situation", "The work environment in this company is safe during a crisis", "Working conditions in times of crisis are satisfactory in the company".

IS, TW and CD were identified as mediator variables. Individual variables are operationalized as scores, obtained on the basis of evaluation of items, which we extracted from the literature review. After reliability analysis, the Cronbach's a of the IS was 0.941 (ten items), TW 0.816 (nine items) and CD 0.881 (four items). Examples of items in the variable IS include: "The information I receive in times of crisis is useful", "I receive information in times of crisis on time", "The information I receive in times of crisis is understandable to me"; TW: "In times of crisis, all team members can ask questions if there is something they do not understand", "Employees receive in times of crisis the support they need from other employees when performing their work", "During a crisis, all employees work together as a well-coordinated team"; CD: "Cognitive diversity is manifested in crisis management by different ways of thinking", " . . by different knowledge and skills", " .. by different perceptions of the world", " ... by different beliefs about right and wrong".

The relationship between the variables CCM, EP, IS, TW and CD can also be influenced by external (control) variables. For control variables, we subsequently verified their influence on the course of the basic investigated/modeled relationship.

\section{Results}

Relationships between individual variables are determined by means of a correlation matrix. To construct it, we created summary variables-CCM, EP, IS, TW and CD as the total average score from the relevant items. Control variables are also included in the matrix, while nominal variables are omitted. Descriptive statistics and the correlation matrix are given in Tables 2 and 3. 
Table 2. Descriptive statistics.

\begin{tabular}{|c|c|c|c|}
\hline Variable & $\begin{array}{c}n \text {-Number of } \\
\text { Respondents }\end{array}$ & Mean & Standard Deviation \\
\hline CCM & 213 & 3.82 & 0.93 \\
\hline TW & 213 & 3.63 & 0.71 \\
\hline IS & 213 & 3.77 & 0.94 \\
\hline $\mathrm{CD}$ & 213 & 3.58 & 0.95 \\
\hline $\mathrm{EP}$ & 213 & 3.87 & 0.74 \\
\hline Gnd. ${ }^{0}$ & 213 & 1.41 & 0.49 \\
\hline Age ${ }^{0}$ & 213 & 2.57 & 1.04 \\
\hline Exp. ${ }^{0}$ & 213 & 2.82 & 1.19 \\
\hline Edu. ${ }^{0}$ & 213 & 2.04 & 0.90 \\
\hline Pos. ${ }^{0}$ & 213 & 2.57 & 0.70 \\
\hline Size ${ }^{0}$ & 213 & 2.45 & 0.62 \\
\hline HTU $^{0}$ & 213 & 1.16 & 0.37 \\
\hline
\end{tabular}

Gnd. = Gender, Exp. = Industry experience, Edu. = Education, Pos. = Position in the management. Variables with

${ }^{0}$ are modified in such a way that the categories are sorted in ascending order.

Table 3. Correlation matrix.

\begin{tabular}{|c|c|c|c|c|c|c|c|c|c|c|c|}
\hline Variable & $\mathrm{CCM}$ & TW & IS & $\mathrm{CD}$ & EP & Gnd. & Age $^{0}$ & Exp. $^{0}$ & Edu. & Pos. ${ }^{0}$ & Size \\
\hline $\mathrm{CCM}$ & - & & & & & & & & & & \\
\hline TW & $0.77^{* *}$ & - & & & & & & & & & \\
\hline IS & $0.86^{* *}$ & $0.72^{* *}$ & - & & & & & & & & \\
\hline $\mathrm{CD}$ & $0.17^{* *}$ & $0.35^{* *}$ & $0.17^{* *}$ & - & & & & & & & \\
\hline $\mathrm{EP}$ & $0.85^{* *}$ & $0.78^{* *}$ & $0.83^{* *}$ & $0.26^{* *}$ & - & & & & & & \\
\hline Gnd. ${ }^{0}$ & $-0.26^{* *}$ & -0.06 & $-0.24 * *$ & -0.01 & $-0.16^{* *}$ & - & & & & & \\
\hline Age $^{0}$ & $-0.25^{* *}$ & $-0.21^{* *}$ & $-0.19 * *$ & $-0.15^{* *}$ & $-0.21^{* *}$ & $-0.20 * *$ & - & & & & \\
\hline Exp. ${ }^{0}$ & $-0.22^{* *}$ & $-0.22^{* *}$ & -0.07 & -0.01 & $-0.19 * *$ & $-0.20^{* *}$ & $0.69^{* *}$ & - & & & \\
\hline Edu. ${ }^{0}$ & 0.04 & 0.10 & 0.12 & 0.04 & 0.12 & -0.01 & $0.24^{* *}$ & $0.16^{* *}$ & - & & \\
\hline Pos. ${ }^{0}$ & -0.01 & -0.07 & -0.02 & -0.07 & 0.00 & -0.10 & $0.21^{* *}$ & $0.28^{* *}$ & -0.12 & - & \\
\hline Size $^{0}$ & -0.02 & 0.00 & 0.11 & 0.00 & -0.05 & 0.09 & $-0.16^{* *}$ & -0.13 & 0.08 & $-0.19^{* *}$ & - \\
\hline $\mathrm{HTU}^{0}$ & -0.06 & -0.04 & -0.06 & 0.04 & -0.07 & 0.09 & -0.05 & -0.06 & 0.00 & -0.07 & 0.07 \\
\hline
\end{tabular}

** $p>0.05$; male $=1$, female $=2$; Bratislava $=2$, Other $=1$. Variables with ${ }^{0}$ are modified in such a way that the categories are sorted in ascending order.

The results of the correlation matrix indicate that there are significantly positive correlations between all five variables examined, indicating the use of a mediator model. In addition to meeting the conditions of mediation, the correlation matrix points to significant connections between CCM and gender (in the negative direction), between CCM and age (in the negative direction) and between CCM and experience (in the negative direction).

In mediation, we based our approach on the established main hypothesis:

Hypothesis 2 (H2). The dependence between competencies of crisis management and employee performance is mediated by the information sharing, teamwork, and cognitive diversity of crisis management.

To model the overall effect, we added the control variables age, gender, experience and position of the manager, the size of the organization and the higher territorial unit. ANOVA was used to analyze the multiple dependence, at a significance level of $5 \%$ and the results obtained are shown in Table 4 . In the nominal variable legal form, we used the following coding: joint stock company (JSC) $=1$ (20 units); agricultural cooperative $=2(54)$; Ltd. $=3$ (139). 
Table 4. Analysis of variance (ANOVA) decomposition—dependent variable EP.

\begin{tabular}{cccccc}
\hline Source & $\begin{array}{c}\text { Type III Sum of } \\
\text { Squares }\end{array}$ & df & $\begin{array}{c}\text { Mean } \\
\text { Square }\end{array}$ & F & Sig. \\
\hline Corrected Model & 87.076 & 10 & 8.708 & 60.214 & 0.0000 \\
Intercept & 1.569 & 1 & 1.569 & 10.851 & 0.0012 \\
LgF 0 & 0.877 & 2 & 0.439 & 3.034 & 0.0503 \\
CCM & 68.072 & 1 & 68.072 & 470.723 & 0.0000 \\
Gdr. & 0.559 & 1 & 0.559 & 3.863 & 0.0507 \\
Age 0 & 0.033 & 1 & 0.033 & 0.229 & 0.6327 \\
Exp. & 0.071 & 1 & 0.071 & 0.493 & 0.4835 \\
Edu. & 0.790 & 1 & 0.790 & 5.465 & 0.0204 \\
Pos. & 0.082 & 1 & 0.082 & 0.567 & 0.4523 \\
Size & 0.007 & 1 & 0.007 & 0.048 & 0.8270 \\
HTU 0 & 0.044 & 1 & 0.044 & 0.301 & 0.5838 \\
Error & 29.211 & 202 & 0.145 & & \\
Total & 3308.066 & 213 & & & \\
Corrected Total & 116.288 & 212 & & &
\end{tabular}

$p>0.05 ;$ male $=1$, female $=2$; Bratislava $=2$, Other $=1$. Variables with ${ }^{0}$ are modified in such a way that the categories are sorted in ascending order.

The distribution of variance for the overall dependence in the baseline model showed that no control variable was significant $(p$-value $<0.05)$.

Subsequently, we proceeded in three steps (A, B, C), in which we verify the partial hypotheses by calculating three regressions.

(C) There is a relationship between EP $(\mathrm{Y})$ and $\mathrm{CCM}(\mathrm{X})$.

(A) There is a relationship between the mediator variable $(M)$ and $C C M(X)$.

(B) There is a relationship between $\mathrm{EO}(\mathrm{Y})$ and the mediator variable $(\mathrm{M})$ in which $\mathrm{X}$ does not participate.

Where $C$ represents the total effect. The product $A^{*} B$ is the mediated (indirect) effect of $X$ on $Y$ through $M$. The difference $C^{\prime}=C-A^{*} B$ is the pure (direct) effect of $X$ on $Y$ without the participation of $\mathrm{M}$. The hypothesis is valid if the indirect effect is significant, i.e., if $A^{*} B=C-C^{\prime}$ is significant, which we confirm by using the Sobel test. The three mediation variables represent the three indirect paths by which the indirect, i.e., mediated relationship will pass through each mediator separately. The path to a direct relationship is also part of the model. The results of the mediation analysis are presented in Table 5 .

The overall relationship between the dependent and independent variable in the baseline model is significant (coefficient $=0.678$, significance $=0.000$ ). Since we used three mediators, we divide the structure of the model into three parts-i.e., the three pathways by which (indirect, i.e., mediated) the relationship will pass through each mediator. Step A (within its steps A1, A2, A3) is significant for two mediation variables (IS and TW), so there is a relationship between the mediation variable (M) and the competencies of crisis management $(X)$ (IS-model 2, coef. $=0.305$, sig. $=0.000$; TW—-model 3, coef. $=1.293$, sig. $=0.000)$. The cognitive diversity mediator was not significant $(C D-$ model 4 , coef. $=2.852$, sig. $=0.180$ ). Step B (steps B1, B2, B3), which represent the relationship between the employee performance of the team $(\mathrm{Y})$ and the mediator variable $(\mathrm{M})$, in which $X$ does not participate, is significant for IS and TW (model 5, IS-coef. $=0.248$, sig. $=0.000$; TW-coef. $=0.239$, sig. $=0.000$ ), is not significant in the case of $C D$ (coef. $=0.042$, sig. $=0.114$ ).

The total indirect effect $\mathrm{A} \times \mathrm{B}=0.359(\mathrm{z}=4.129$, sig. $=0.000)$ is significant and the dependence is positive. Indirect effects mediated through individual mediators are significant for two variables-IS and TW (for IS Ai $\times \mathrm{Bi}=0.213, \mathrm{Zi}=4.958$, sig. = 0.000; for $\mathrm{TW}$ is $\mathrm{Ai} \times \mathrm{Bi}=0.138, \mathrm{Zi}=4.130$, sig. $=0.000)$, insignificant in the case of the $\mathrm{KD}$ variable $(\mathrm{Ai} \times \mathrm{Bi}=0.007, \mathrm{Zi}=1.342$, sig. $=0.180)$. As the direct effect of $\mathrm{C}$ is also significant, multifaceted incomplete mediation has been proved. The size of the effect of the individual components of the model used is shown in Table 6. 
Table 5. Regression results for main effects and mediation analysis.

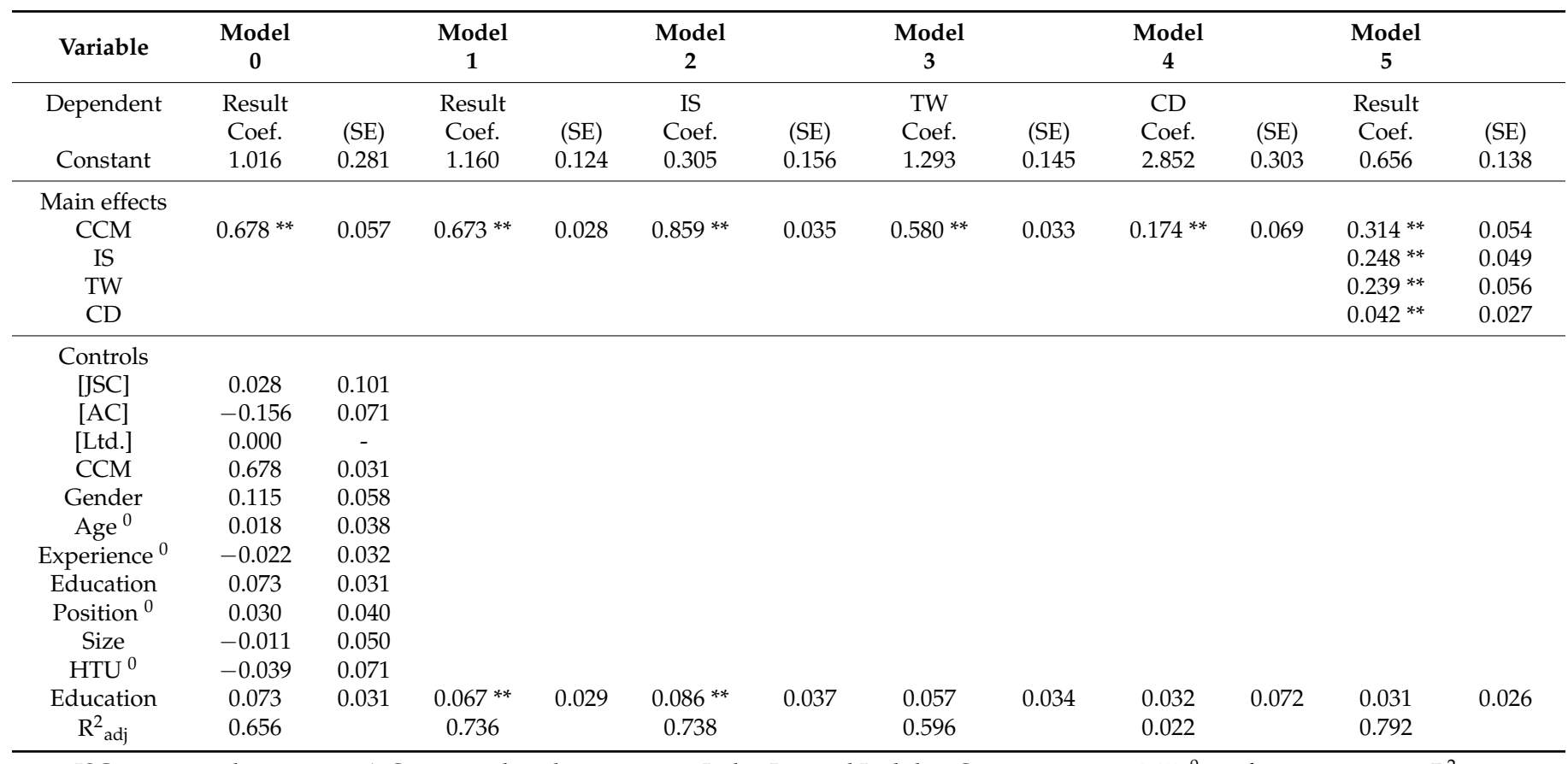

JSC—joint stock company; A.C.—agricultural cooperative; Ltd.-Limited Liability Company; ${ }^{* *} p>0.05 ;{ }^{0}$-reference category; $\mathrm{R}^{2}$ adj adjusted coefficient of determination, SE-standard error of the estimate.

Table 6. Overall mediation.

\begin{tabular}{ccc}
\hline Effect & Coef. & $\%$ \\
\hline Overall & 0.673 & $100 \%$ \\
\hline Direct & 0.314 & $47 \%$ \\
Indirect & 0.359 & $53 \%$ \\
\hline Indirect through M1-IS & 0.213 & \\
Indirect through M2-TW & 0.138 & \\
Indirect through M3-CD & 0.007 & \\
\hline
\end{tabular}

The indirect effect is higher in percentage (53\%), which means that the mediated action of CCM on EP is slightly more significant than the direct action of these two variables $(47 \%)$, i.e., the individual mediator variables intensify this effect. Within indirect action, information sharing has the greatest impact-almost $60 \%$ of the indirect effect. $38.4 \%$ of the indirect effect is mediation through teamwork. The transfer of the effect through the cognitive diversity of the members of the crisis management has an insignificant influence $(1.6 \%)$.

\section{Discussion and Conclusions}

Through mediation, we found that the relationships expressed by steps A and B are significant in the case of two mediating variables, confirming the existence of statistically significant positive correlations between information sharing (M1) and competencies of crisis management $(X)$ and between teamwork (M2) and competencies of crisis management $(\mathrm{X})$. At the same time, there are relationships of employee performance $(\mathrm{Y})$ and two intermediate variables (M1, M2), in which X does not participate. Due to the significance of these relationships, a precondition for the existence of mediation arises.

The indirect effect is significant, which means that the effect of competencies of crisis management $(\mathrm{X})$ on the performance of agricultural employees $(\mathrm{Y})$ through measured information sharing and teamwork has been statistically confirmed. Based on the aforementioned, we confirm the formulated main hypothesis. 
Both indirect and direct effects are significant. In percentage terms, about $47 \%$ of the total effect is due to the direct effect and about 53\% to the indirect effect. As the indirect effect does not reach more than $80 \%$ of the total effect, it represents a partial mediation.

Both hypotheses 1 and 2 of a dependence between competencies of crisis management and the performance of agricultural employees, which is mediated by information sharing, teamwork and cognitive diversity, has been confirmed. Partial mediation has been identified, since only part of the effect is mediated by mediator variables; however, it is the larger part.

The remaining, smaller part is mediated directly. However, an important result is that in the acute crisis phase, the performance of agricultural employees can be influenced by competent crisis management and its effect enhanced by sharing information and supporting teamwork. Cognitive diversity of crisis management-presented by some aforementioned studies as an important factor influencing the performance of employees by the diversity of opinions, attitudes, perspectives, etc.- did not prove significant in our study and in the conditions of the Slovak Republic.

The competence of crisis management needs to be shaped differently in the sector of agricultural enterprises. First, through the skills of crisis communication, leadership, and decision making, making the findings of our study consistent with those of other published studies [1,21,29,53]. However, our findings also show that these skills are not sufficient enough, or rather transmit only a small part of the effect. Teamwork and especially information sharing are becoming important, increasing the impact of competencies of crisis management on employee performance.

The subjective feelings of employees in the acute phase of the crisis are significantly influenced by feelings of threat, insecurity, and fear. Therefore, familiarity with the procedures for resolving the crisis situation, the regularity of information supply, its timeliness and at the same time sufficiency, are highly valued by employees. Employees need to have an overall picture of the situation; they need transparency and constant updating of the information provided. Appropriate communication channels for interception and fast, understandable and regular delivery in various unforeseen situations are also highly rated. Teamwork has supportive effects in different situations.

In the acute phase of the crisis, teamwork proved to be a slightly less important mediating factor in the transfer of the effect of competencies of crisis management on employee performance. The impact, however, was also significant. Employees declared the importance of items of mutual support (not only the professional one), assistance, explanation, minimization of conflicts, or their constructive resolution, reduction of concerns and coordination of work.

Since in our study the indirect effect was observed in the form of three variables, the strength of its action was divided into these three parts and the effect of TW was, therefore, weaker only in comparison with IS. If we examined only TW as a mediation variable, its indirect effect would be higher and, therefore, we can conclude that our findings are consistent with the findings of other studies on the significance of TW in crisis conditions [71,73-75].

Younger employees and, in terms of gender, women, have a more favorable perception of competent managers, their way of leading, communicating and making decisions, as well as sharing information and creating conditions for teamwork. Dependencies are statistically significant.

Other factors such as education, position in management, company size and higher territorial unit do not have a significant impact on employees' views on competencies of their superiors in crisis. Therefore, we can conclude that the findings are generally applicable and usable in the conditions of agricultural enterprises in Slovak Republic and other Central and Eastern European countries. Partly surprising was the finding that cognitive diversity in the crisis management of agricultural enterprises does not significantly affect the performance of employees. Given the published studies on its importance in relation 
to innovative behavior $[65,77]$ and team performance $[78,79]$, we assumed a higher impact in times of acute crisis.

Cognitive diversity supports the quality of decision making in a crisis, because it is a source of diversity of perspectives and thus has a positive effect on the performance of employees. In our study, only the diversity of knowledge and skills (vocational agricultural) was applied and used to the greatest extent, which enabled qualified decisions to be made. Value diversity (leadership differs in how the world is seen and beliefs about what is bad and what is good) and diversity of thinking were lower, which in our view may have influenced results in terms of low indirect effect of cognitive diversity in the relationship between CCM and EP. Consistency in important aspects of diversity is essential to reassure employees in times of health crisis and to ensure that the various solutions are discussed which would help to ensure the optimal conditions for their work.

\section{Conclusions}

The COVID-19 pandemic has had an unprecedented impact on society and the economy. It represents a health crisis, sensitively perceived by every citizen, because it threatens human health, but at the same time, it causes a deep economic crisis with long-term consequences and the need for effective solutions. Owners, managers and employees of agricultural enterprises and all actors involved in the food supply chain had to work hard to ensure that the supply of quality and safe food was not jeopardized at the time of the outbreak and the declaration of emergencies. Although the governments of states around the world seek to maintain food security by taking various measures to ensure the smooth flow of food, they also must make efforts to ensure food self-sufficiency and create the conditions for the competitiveness of its farmers. Likewise, agricultural managers must subsequently create conditions for the quality and safe performance of their subordinates. Agriculture is increasingly coming to the attention of the scientific community in order to fulfill its many functions, not only in relatively peaceful times, but also in times of crisis.

Our research has both theoretical and practical implications. At the theoretical level, it enriches the literature in the field of crisis management with the perception of employee performance in the acute phase of the crisis from a different perspective, namely the multifactor concept of the working climate of employees and the possibility of studying it from many different perspectives. Our research summarizes the views of many authors on CCM in times of crisis and compresses them into a common CCM variable that can be a construct for further research. At the same time, the research model of our study, established by the identified research gap, reveals the mechanism of interaction between CCM and EP, which is both direct but also mediated by other variables, namely TW and IS.

We see the practical implications of our research on several levels. First, the crisis is a unique situation that will not be resolved by doing business as usual, however, with more effort. The key to success is "hard thinking", the ability to work with estimates, assumptions and lack of information, not (only) "intense work." Second, crisis management supports employee performance when crisis management is competent, credible, transparent and restores certainty to a certain (possible) degree. At the acute stage, employees especially appreciate honesty, sincerity, transparency, positive perception and mutual empathy. They expect management to control the situation, explain, provide guidance, support and trust. These aspects of managers' competency are significantly reflected in the performance of employees, since their feelings of satisfaction, safety, and security influence it. The link between the psychological safety of employees and the performance of the company is obvious.

Third, the competence of crisis management positively influences the performance of employees in particular by sharing information. Employees appreciate it if they are familiar with the crisis management process, if they have enough information for their work, and the information is constantly updated. Lack of information overload is not appropriate because it increases uncertainty, fear and anxiety. Negative emotions subsequently reduce performance, the ability to respond adequately, to think innovatively, to submit proposals, 
to express opinions, often even critical ones, which are necessary at this stage. Information must be disseminated quickly but reliably. Confidential and strategic information is shared within the crisis staff. If this information is disclosed to another interested party or to anyone else, at a time other than planned, it can lead to a communication disaster. Therefore, prudence and transparency are key issues and both must be part of professional integrity.

Fourth, competence of crisis management positively affects performance by strengthening team-level autonomy and promoting teamwork. During crisis times, employees appreciate if they receive the support they need from other employees and management in the performance of their work. Support provides them with the necessary confidence, feeling of safety and satisfaction, and at the same time they appreciate the fact that all team members can ask questions if there is something they do not understand, they can express themselves critically, encourage, provide feedback.

Fifth, the competence of crisis management is not significantly supported by the cognitive diversity of the crisis team; on the contrary, consistency of opinions is a source of certainty and transparency of managerial decisions. For the performance of agricultural employees, it is not important whether team members differ in ways of thinking, in knowledge and skills, in perceptions of the world or in beliefs about right and wrong. Dominant, trustworthy, convincing leadership is important.

The final practical implication of our research is that communication and cooperation are important tools for managing employee performance, defined by the current COVID19 pandemic, and on which management may continue to focus in the event of similar crises. The results of the research have been provided to the agricultural companies, which participated in the research and can thus be directly taken into account in their own management.

Our research has several limitations. The first is the research sample, which was not selected randomly. All respondents were contacted on the basis of their inclusion in the database of agricultural enterprises in Slovakia with the assumption of a low return on responses. Nevertheless, companies of various legal forms, of various sizes and from all higher territorial units of Slovak Republic were represented in the sample. The second limitation of the interpretation of research results is the fact that it is of a local nature. From a regional point of view, the results are relevant, for the generalization it would be appropriate to enlarge the sample. However, due to the universal conditions in which agricultural enterprises operate, we assume that the results of the research can be applicable without a direct link to the region where the research itself took place and have international applicability.

Author Contributions: Conceptualization, N.J. and J.M.; methodology, N.J.; software, J.M.; validation, N.J.; formal analysis, N.J.; investigation, J.M.; resources, J.M.; data curation, N.J.; writingoriginal draft preparation, N.J.; writing - review and editing, J.M.; visualization, J.M.; supervision, N.J.; project administration, J.M.; funding acquisition, N.J. All authors have read and agreed to the published version of the manuscript.

Funding: This research was funded by Scientific Grant Agency VEGA of the Ministry of Education, Science, Research and Sport of the Slovak Republic, grant number 1/0017/20 and grant number $1 / 0328 / 21$ with a share of $50 \%$.

Institutional Review Board Statement: Not applicable.

Informed Consent Statement: Not applicable.

Data Availability Statement: The data presented in this study are available on request from the corresponding author.

Conflicts of Interest: The authors declare no conflict of interest. 


\section{References}

1. Bowers, M.R.; Hall, J.R.; Srinivasan, M.M. Organizational culture and leadership style: The missing combination for selecting the right leader for effective crisis management. Bus. Horiz. 2017, 60, 551-563. [CrossRef]

2. Sheth, J. Business of business is more than business: Managing during the Covid crisis. Ind. Mark. Manag. 2020, 88, 261-264. [CrossRef]

3. Rakshit, B.; Basistha, D. Can India stay immune enough to combat COVID-19 pandemic? An economic query. J. Public Aff. 2020, 20, e2157. [CrossRef] [PubMed]

4. Lal, R. Home gardening and urban agriculture for advancing food and nutritional security in response to the COVID-19 pandemic. Food Sec. 2020, 12, 871-876. [CrossRef] [PubMed]

5. Zhang, S.; Wang, S.; Yuan, L.; Liu, X.; Gong, B. The impact of epidemics on agricultural production and forecast of COVID-19. China Agric. Econ. Rev. 2020, 12, 409-425. [CrossRef]

6. Gray, R.S. Agriculture, transportation, and the COVID-19 crisis. Can. J. Agric. Econ. 2020, 68, 239-243. [CrossRef]

7. Gregorioa, G.B.; Ancog, R.C. Assessing the impact of the covid-19 pandemic on agricultural production in Southeast Asia: Toward transformative change in agricultural food systems. Asian J. Agric. Dev. 2020, 17, 1-14. [CrossRef]

8. Pulighe, G.; Lupia, F. Food first: COVID-19 outbreak and cities lockdown a booster for a wider vision on urban agriculture. Sustainability 2020, 12, 5012. [CrossRef]

9. Henry, R. Innovations in agriculture and food supply in response to the COVID-19 pandemic. Mol. Plant 2020, 13, 1095-1097. [CrossRef]

10. Altieri, M.A.; Nicholls, C.I. Agroecology and the reconstruction of a post-COVID-19 agriculture. J. Peasant Stud. 2020, 47, 881-898. [CrossRef]

11. Bergström, J.; Uhr, C.; Frykmer, T. A complexity framework for studying disaster response management. J. Conting. Crisis Manag. 2016, 24, 124-135. [CrossRef]

12. Yu, M.; Li, Z.; Yu, Z.; He, J.; Zhou, J. Communication related health crisis on social media: A case of COVID-19 outbreak. Curr. Issues Tour. 2020, 1-7. [CrossRef]

13. Moerschell, L.; Novak, S.S. Managing crisis in a university setting: The challenge of alignment. J. Conting. Crisis Manag. 2020, 28, 30-40. [CrossRef]

14. Verma, S.; Gustafsson, A. Investigating the emerging COVID-19 research trends in the field of business and management: A bibliometric analysis approach. J Bus. Res. 2020, 118, 253-261. [CrossRef] [PubMed]

15. Ratten, V. Coronavirus (covid-19) and entrepreneurship: Changing life and work landscape. J. Small Bus. Entrep. 2020, 1-14. [CrossRef]

16. Tourish, D. Introduction to the special issue: Why the coronavirus crisis is also a crisis of leadership. Leadership 2020, 16, 261-272. [CrossRef]

17. Grint, K. Leadership, management and command in the time of the Coronavirus. Leadership 2020, 16, 314-319. [CrossRef]

18. Wilson, S. Pandemic leadership: Lessons from New Zealand's approach to COVID-19. Leadership 2020, 16, 279-293. [CrossRef]

19. Wisittigars, B.; Siengthai, S. Crisis leadership competencies: The facility management sector in Thailand. Facilities 2019, 37, 881-896. [CrossRef]

20. Trachsler, T.; Jong, W. Crisis management in times of COVID-19: Game, set or match? J. Conting. Crisis Manag. 2020, 1-2. [CrossRef]

21. Comfort, L.; Kapucu, N.; Ko, K.; Menoni, S.; Siciliano, M. Crisis Decision Making on a Global Scale: Transition from Cognition to Collective Action under Threat of COVID-19. Public Adm. Rev. 2020, 80, 616-622. [CrossRef] [PubMed]

22. Moon, M.J. Fighting Against COVID-19 with Agility, Transparency, and Participation: Wicked Policy Problems and New Governance Challenges. Public Adm. Rev. 2020, 80, 651-656. [CrossRef] [PubMed]

23. Claeys, A.S.; Coombs, W.T. Organizational crisis communication: Suboptimal crisis response selection decisions and behavioral economics. Commun. Theory 2019, 30, 290-309. [CrossRef]

24. Kraus, S.; Clauss, T.; Breier, M.; Gast, J.; Zardini, A.; Tiberius, V. The economics of COVID-19: Initial empirical evidence on how family firms in five European countries cope with the corona crisis. Int. J. Entrep. Behav. Res. 2020, 26, 1067-1092. [CrossRef]

25. Stephens, K.K.; Jahn, J.L.S.; Fox, S.; Charoensap-Kelly, P.; Mitra, R.; Sutton, J.; Meisenbach, R.J. Collective Sensemaking Around COVID-19: Experiences, Concerns, and Agendas for our Rapidly Changing Organizational Lives. Manag. Commun. Q. 2020, 34, 426-457. [CrossRef]

26. Al-Dabbagh, Z.S. The Role of Decision-maker in Crisis Management: A qualitative Study Using Grounded Theory (COVID19 Pandemic Crisis as A Model). J. Public Aff. 2020, 20, e2186. [CrossRef]

27. Kash, B.A.; Cheon, O.; Halzack, N.M.; Miller, T.R. Measuring Team Effectiveness in the Health Care Setting: An Inventory of Survey Tools. Health Serv. Insights 2018, 11, 117863291879623. [CrossRef]

28. Abo-Murad, M.; Abdullah, A.K. Turnover culture and crisis management: Insights from Malaysian hotel industry. Acad. Strateg. Manag. J. 2019, 18, 1-14.

29. Bhaduri, R.M. Leveraging culture and leadership in crisis management. Eur. J. Train. Dev. 2019, 43, 554-569. [CrossRef]

30. Shangguan, Z.; Wang, M.Y.; Sun, W. What Caused the Outbreak of COVID-19 in China: From the Perspective of Crisis Management. Int. J. Environ. Res. 2020, 17, 3279. [CrossRef] 
31. Tokakis, V.; Polychroniou, P.; Boustras, G. Crisis management in public administration: The three phases model for safety incidents. Saf. Sci. 2019, 113, 37-43. [CrossRef]

32. Bernstein, J. The 10 Steps of Crisis Communications. Available online: https://www.bernsteincrisismanagement.com/the-10 -steps-of-crisis-communications (accessed on 3 September 2020).

33. Ulmer, R.R.; Sellnow, T.L.; Seeger, M.W. Effective Crisis Communication: Moving from Crisis to Opportunity, 4th ed.; SAGE Publications: Thousand Oaks, CA, USA, 2017; p. 6.

34. Kim, Y.; Lim, H. Activating constructive employee behavioural responses in a crisis: Examining the effects of pre-crisis reputation and crisis communication strategies on employee voice behaviours. J. Conting. Crisis Manag. 2020, 28, 141-157. [CrossRef]

35. Clementson, D.E. Narrative persuasion, identification, attitudes, and trustworthiness in crisis communication. Public Relat. Rev. 2020, 101889. [CrossRef]

36. Boin, A.; Hart, P.; Stern, E.; Sundelius, B. The Politics of Crisis Management: Public Leadership Under Pressure; Cambridge University Press: Cambridge, UK, 2017.

37. Helsloot, I.; Groenendaal, J. It's meaning making, stupid! Success of public leadership during flash crises. J. Conting. Crisis Manag. 2017, 25, 350-353. [CrossRef]

38. You, M.; Ju, Y. Salience of public leaders' "meaning making" in news coverage of a health crisis. J. Conting. Crisis Manag. 2019, 27, 400-405. [CrossRef]

39. Moitroux, P.; Maloney, P. Komunikation macht den Unterschied. Personalmagazin 2020, 5/2020, 36-38.

40. Reynolds, B.; Seeger, M.W. Crisis and emergency risk communication as an integrative model. J. Health Commun. 2005, 10 , 43-57. [CrossRef]

41. Argenti, P.A. Communicating Through the Coronavirus Crisis. Harvard Business Review. 2020. Available online: https: //hbr.org/2020/03/communicating-through-the-coronavirus-crisis (accessed on 24 August 2020).

42. Argenti, P.A. Crisis Communication: Lessons from 9/1. Harv. Bus. Rev. 2002, 80, 103-109.

43. Mayo, A.T. Teamwork in a pandemic: Insights from management research. BMJ Lead. 2020, 4, 53-56. [CrossRef]

44. Tannenbaum, S.I.; Traylor, A.M.; Thomas, E.J.; Salas, E. Managing teamwork in the face of pandemic: Evidence-based tips. BMJ Quality \& Safety 2021, 30, 59-63. [CrossRef]

45. Johansson, C.; Ottestig, A.T. Communication executives in a changing world: Legitimacy beyond organizational borders. J. Commun. Manag. 2011, 15, 144-164. [CrossRef]

46. Vos, S.C.; Buckner, M.M. Social Media Messages in an Emerging Health Crisis: Tweeting Bird Flu. J. Health Commun. 2016, 21, 301-308. [CrossRef] [PubMed]

47. Coombs, W.T. Protecting organization reputations during a crisis: The development and application of situational crisis communication theory. Corp. Reput. Rev. 2007, 10, 163-176. [CrossRef]

48. Strack, J.; Dyrchs, S.; Baier, J. Mit Plan durch die Krise und weiter. Personalmagazin 2020, 5/2020, 28.

49. Richardson, N. Book review: Crisis leadership: How to lead in times of crisis, threat and uncertainty. Manag. Learn. 2019, 50, 629-632. [CrossRef]

50. Grant-Smith, D.C.C.; Colley, L.K. Of 'Strong' Leadership, Crisis Communication, and Pooper Scoopers: Change in the Queensland Public Service under Newman. Aust. J. Public Adm. 2018, 77, 236-252. [CrossRef]

51. Kapucu, N.; Ustun, Y. Collaborative Crisis Management and Leadership in the Public Sector. Int. J. Public Adm. 2018, 41, 548-561. [CrossRef]

52. James, E.H.; Wooten, L.P.; Duskek, K. Crisis management: Informing a new leadership research agenda. Acad. Manag. Ann. 2011, 5, 455-493. [CrossRef]

53. Pearce, A.P.; Naumann, D.N.; O’Reilly, D. Mission command: Applying principles of military leadership to the SARS-Cov-2 (covid-19) crisis. BMJ Mil. Health 2020. [CrossRef]

54. Savi, R.; Randma-Liiv, T. Decision-making in time of crisis: Cutback management in Estonia. Int. Rev. Adm. Sci. 2015, 81, 479-497. [CrossRef]

55. Stanton, T.H. Risk Management and Decision Making: Lessons from the Financial Crisis for Federal Managers. In Managing Risk and Performance; Stanton, T.H., Webster, D.W., Eds.; John Wiley \& Sons: Hoboken, NJ, USA, 2014.

56. Higgins, G.; Freedman, J. Improving decision making in crisis. J. Bus. Contin. Emer. Plan. 2013, 7, 65-76. [PubMed]

57. Obrenovic, B.; Du, J.; Godinic, D.; Tsoy, D.; Khan, M.A.S.; Jakhongirov, I. Sustaining Enterprise Operations and Productivity during the COVID-19 Pandemic: "Enterprise Effectiveness and Sustainability Model". Sustainability 2020, 12, 5981. [CrossRef]

58. Reeves, M.; Lang, N.; Carlsson-Szlezak, P. Lead Your Business through the Coronavirus. Harvard Business Review. 2020. Available online: https:/ /hbr.org/2020/02/lead-your-business-through-the-coronavirus-crisis (accessed on 3 June 2020).

59. Goniewicz, K.; Khorram-Manesh, A.; Hertelendy, A.J.; Goniewicz, M.; Naylor, K.; Burkle, F.M. Current Response and Management Decisions of the European Union to the COVID-19 Outbreak: A Review. Sustainability 2020, 12, 3838. [CrossRef]

60. Van der Vegt, G.S.; Janssen, O. Joint Impact of Interdependence and Group Diversity on Innovation. J. Manag. 2003, 29, 729-751. [CrossRef]

61. Shin, S.J.; Kim, T.Y.; Lee, J.Y.; Bian, L. Cognitive team diversity and individual team creativity: A crosslevel interaction. Acad. Manag. J. 2012, 55, 197-212. [CrossRef]

62. MacLeod, D.; Clarke, N. Engaging for Success: Enhancing Performance through Employee Engagement, a Report to Government; Office of Public Sector Information, Richmond Surrey: Richmond, UK, 2011. 
63. Spurgeon, P.; Mazelan, P.M.; Barwell, F. Medical engagement: A crucial underpinning to organizational performance. Health Serv. Manag. Res. 2011, 24, 114-120. [CrossRef] [PubMed]

64. Vainieri, M.; Ferrè, F.; Giacomelli, G.; Nuti, S. Explaining performance in health care. Health Care Manag. Rev. 2017, 44, 306-317. [CrossRef] [PubMed]

65. Mitchell, R.; Boyle, B.; O’brien, R.; Malik, A.; Tian, K.; Parker, V.; Chiang, V. Balancing cognitive diversity and mutual understanding in multidisciplinary teams. Health Care Manag. Rev. 2017, 42, 42-52. [CrossRef]

66. Kim, T.-Y.; David, E.M.; Liu, Z. Perceived Cognitive Diversity and Creativity: A Multilevel Study of Motivational Mechanisms and Boundary Conditions. J. Creat. Behav. 2020. [CrossRef]

67. Srivastava, A.; Bartol, K.M.; Locke, E.A. Empowering leadership in management teams: Effects on knowledge sharing, efficacy, and performance. Acad. Manag. J. 2006, 49, 1239-1251. [CrossRef]

68. Aragon-Correa, J.A.; Martin-Tapia, I.; Hurtado-Torres, N.E. Proactive environmental strategies and employee inclusion: The positive effects of information sharing and promoting collaboration and the influence of uncertainty. Organ. Environ. 2013, 26, 139-161. [CrossRef]

69. Dahlin, K.B.; Weingart, L.R.; Hinds, P.J. Team diversity and information use. Acad. Manag. J. 2005, 48, 1107-1123. [CrossRef]

70. Wang, X.; Kim, T.; Lee, D. Cognitive diversity and team creativity: Effects of team intrinsic motivation and transformational leadership. J. Bus. Res. 2016, 69, 3231-3239. [CrossRef]

71. Abdolshah, M.; Khatibi, S.A.M.; Moghimi, M. Factors influencing job satisfaction of banking sector employees. J. Cent. Bank. Theory Pract. 2018, 7, 207-222. [CrossRef]

72. Guillon, O.; Cezanne, C. Employee loyalty and organizational performance: A crucial survey. J. Organ. Chang. Manag. 2014, 27, 839-850. [CrossRef]

73. Nedkovski, V.; Guerci, M.; Battisti, F.; Siletti, E. Organizational ethical climates and employee's trust in colleagues, the supervisor, and the organization. J. Bus. Res. 2017, 71, 19-26. [CrossRef]

74. Bogan, E.; Dedeoglu, B.B. The effects of perceived behavioral integrity of supervisors on employee outcomes: Moderating effects of tenure. J. Hosp. Mark. Manag. 2017, 26, 511-531.

75. Ali, M.; Lei, S.; Wei, X. The mediating role of the employee relations climate in the relationship between strategic HRM and organizational performance in Chinese banks. J. Innov. Knowl. 2018, 3, 115-122. [CrossRef]

76. McGuire, M.J.; Noronha, G.; Samal, L.; Yeh, H.C.; Crocetti, S.; Kravet, S. Patient safety perceptions of primary care providers after implementation of an electronic medical record system. J. Gen. Intern. Med. 2013, 28, 184-192. [CrossRef]

77. Kilduff, M.; Angelmar, R.; Mehra, A. Top management-team diversity and firm performance: Examining the role of cognitions. Organ. Sci. 2000, 11, 21-34. [CrossRef]

78. Chow, I.H.S. Cognitive diversity and creativity in teams: The mediating roles of team learning and inclusion. Chin. Manag. Stud. 2018, 12, 369-383. [CrossRef]

79. Horwitz, S.K. The compositional impact on team diversity on performance: Theoretical consideration. Hum. Resour. Dev. Rev. 2005, 4, 219-245. [CrossRef] 